The Quarterly Journal of Austrian Economics

Volume 22 | No.3 | 383-427 | Fall 2019

WWW.QJAE.ORG

\title{
Over the Cliff: How Brazil's 2004-2016 Business Cycle Became Its Worst Recession in a Century
}

\author{
Henrique Lyra Maia, Dale Steinreich, and Bruno \\ Saboia de Albuquerque*
}

JEL Classification: E14, E21, E31, E32, E51, E52

Aвstract: This paper analyzes Brazil's 2004-16 business cycle, which subsumes what is now regarded as the nation's most severe macroeconomic recession in more than a century. During the steep recession, which stretched over more than two years, national production at one point fell 3.8 percent per annum while the unemployment rate rose from 4.6 to as high as 11.9 percent. This study, after delineating its methodology, examines the behavior of different Brazilian macroeconomic aggregates during the cycle. These aggregates include GDP, the money supply, interest rates, savings, industrial production of higher- and lower-order goods, and inflation. Also examined are the Brazilian government's interventions that rearranged Brazil's structure of production and ignited an unsustainable boom, the role of price controls in prolonging economic recovery, and the recovery per se using the theoretical lens of the Austrian-adjustment process. Finally, empirical data from the recent Brazilian cycle will be analyzed in light of the predictions of Austrian business cycle theory (ABCT). The data were found overall to support the theory.

\footnotetext{
*Henrique Lyra Maia (henriquelyramaia@gmail.com) is a doctoral student at FUCAPE Business School (Vitoria, Brazil). Dale Steinreich (dsteinreich@drury.edu) is an instructor of economics at Drury University. Bruno Saboia de Albuquerque (brunosaboia@alu.ufc.br) is a researcher in economics at Universidade Federal do Ceará. The authors wish to thank the Grant Aldrich Committee of the Austrian Economics Research Conference (AERC) 2018 for making an earlier version of this paper a Grant-Aldrich Prize finalist, and Timothy D. Terrell, Joseph T. Salerno, Robert Barclay, and two anonymous referees for their encouragement and guidance.
} 


\section{INTRODUCTION}

T $\mathrm{t}$ has long been recognized in Brazil that the nation's economy Lhas tremendous difficulty sustaining long-term growth. Brazilian economists jokingly call this "the flight of the chicken," referring to the fact that among birds, chickens are only capable of flying a maximum distance of a few hundred feet. In the same way, Brazil's economy typically enters a period of impressive-looking growth before this growth quickly gives way to crisis or stagnation. This has happened over and over again.

The central macroeconomic debate in Brazil has been about the real causes of the nation's lack of sustained growth. Motivated by this discussion, this article will deconstruct Brazil's latest economic boom and bust in light of Austrian business cycle theory (ABCT), using $\mathrm{ABCT}$ to explain the recent cycle's causes and why this period became yet another "flight of the chicken."

The recent crisis carries a special meaning for Brazilians. It is the most severe recession since GDP measurement was introduced in Brazil in 1901. It persisted over two full and consecutive years, inflicting an annual decline in GDP of more than 3 percent. ${ }^{1}$ In the boom, the unemployment rate fell to 4.6 percent before skyrocketing to 11.9 percent ${ }^{2}$ during the bust. This was the most agonizing crisis for Brazilians in at least 115 years (Cury and Silveira 2017).

The most important features of $\mathrm{ABCT}$ were first introduced by Mises $(2008,2009)$, amended with lengthy contributions from Hayek (1931, 1933, 2008), Rothbard (2000, 2009), and Garrison (1978, 1997, 2001, 2004, 2012). Recently, another set of articles was published, each article making new contributions (Carilli and Dempster 2001, Evans and Baxendale 2008, Macovei 2015, Engelhardt 2012, Salerno 2012, Giménez Roche 2014). For Brazil's economy during the 2004-16 business cycle, data for all the macroeconomic variables relevant to $\mathrm{ABCT}$ have been obtained.

\footnotetext{
${ }^{1}$ As the recession entered 2017, the authors ended their analysis for this study at December 2016. Subsequent sections in this article will provide deeper analysis of the data discussed in this paragraph.

${ }^{2}$ For these data, the authors used two different series because one was discontinued in February 2016. For the boom phase, the Central Bank of Brazil's (Banco Central do Brasil, BCB for short) series number is 10777. The series for the bust phase is 24369 .
} 
This article is divided into nine sections. After this brief introduction (section one), section two will introduce $\mathrm{ABCT}$ and its main theorists. Section three will explain the methodological aspects of this study while section four will deconstruct the recent Brazilian cycle into distinct phases for a better understanding of the whole. For the reader, this fourth section is key to interpreting and understanding data presented later in the article. Sections five and six will be dedicated to explaining in detail phase two ("reset" and the New Matrix boom) and phase three (bust) and how government intervention re-arranged Brazil's structure of production. Section seven will analyze the inflation component of the business cycle and how government price controls postponed Brazil's recovery. The eighth section will summarize all the results from the data and make some final observations. Finally, the last section (nine) will conclude this study.

\section{AUSTRIAN BUSINESS CYCLE THEORY (ABCT)}

Economic transactions occur when individuals pursue their objectives (Mises 2008, 11). Every individual analyzes the costs and benefits of searching for information and gaining knowledge to achieve his or her goals (Mueller 2014). However, individuals do not possess all the information available in the economy. Each individual only retains the bits of knowledge that he or she uses for his or her own purposes (Hayek 1945).

Considering that economic transactions and knowledge are dispersed, it is difficult to conceive of how markets can act in synchrony over the long term. People have diverse goals and act in different ways. As a consequence, only small clusters of errors are theoretically possible, restricted to relatively few firms (Rothbard $2009,17)$. It would be just about impossible for all firms in the entire economy to go bankrupt in unison. In other words, when business cycles-a boom followed by a bust--occur, it is rational to attribute an external variable as the force that is influencing individuals to engage in systemic entrepreneurial error (Rothbard 2000, 9). Hence, in an unhampered market a massive crisis will not be possible (Mises 2008, 562).

Instead of boom and bust, economic development aims for a more sustained growth model. To avoid creating cycles and systemic 
economic instability, economic transactions must be built upon stronger foundations. There are three major sources of sustainable growth for an economy. The first is increasing levels of voluntary savings from individuals. When true voluntary savings are accumulated, consumer time preferences guide entrepreneurial action towards projects in alignment with consumer preferences (Manish and Powell 2014).

In the aggregate, extra savings reallocates capital that would have been spent on consumption to loanable-funds markets for investment projects (Garrison 1997). With an increase in the supply of loanable funds, the real interest rate falls and more capital projects are undertaken. Capital-intensive projects are very interest-rate sensitive. Many projects can become economically viable when capital becomes cheaper. When this happens, the structure of production changes to a more lengthy (Hayek 1936) and prolific (Hayek 2008) modus operandi. In the long run, the more productive investment in roundabout ${ }^{3}$ methods of production will more than compensate for the fall in consumer prices as a consequence of less short-term consumption (Hayek 1931). When a nation invests in capital projects, its production-possibilities frontier is extended and this extension yields a more solid foundation for future growth (Garrison 2012).

When individuals in a nation have not saved enough such that interest rates in loanable-funds markets fall, external savings (foreign-direct investment) can be another route to sustainable growth (Mises 2006, 75). Foreign investors who have the savings to undertake capital projects can fill in the domestic gap in savings needed to initiate or maintain sustainable growth.

The other way to achieve sustainable growth is with more efficient methods of production and intangible capital (Young 2009a). Technology would certainly mean consuming less resources to produce more output, leading the economy to extend its production-possibilities frontier (Garrison 2012). Productivity can lead to sustainable growth because individuals can produce a larger quantity of output

\footnotetext{
${ }^{3}$ This term is usually used in capital theory to denote a more capital-intensive method of production. Sometimes Hayek also used "capitalistic methods," "roundaboutness," or "roundabout methods of production." These terms are synonymous (Hayek 2008).
} 
with less input, which ultimately increases individuals' earnings. It is possible for entrepreneurs to engage in new capital projects while consumption is expanding (Mises 2008, 512-13).

Even if time preferences stay constant, with more productivity more money becomes available for entrepreneurs to engage in more projects, leading to sustainable economic growth (Young 2009a, Engelhardt 2009, Young 2009b). Despite the fact that sustainable growth can be created by increasing productivity, if time preferences are not lowered, entrepreneurial projects will encounter limits. In other words, for a longer and more productive structure of production, individuals' time preferences will have to be lowered (Salerno 2001, Cochran 2001). Higher productivity increases wealth, which in turn can motivate individuals to lower their time preferences (Block, Barnett, and Salerno 2006). However, it might be the case that individuals can spend all their extra earnings and continue to increase their time preferences. As a result, increased productivity can only lead to a fall in interest rates if individuals, with higher earnings, lower their time preferences. The decision by individuals to lower their time preferences after they become more productive is a function of each individual's preference, not a fact.

If individuals in a given society do not pursue goals that encourage greater savings and/or lower time preferences, stagnation and slow growth are the results. Changing these variables (savings/ time preferences) in the direction that facilitates growth takes time and effort. If government intervenes in the form of shortcuts, the economy can be steered onto an unsustainable path (Garrison 2004). Government interventions can take myriad forms and stifle the economic development of a society (Mises 2011).

In terms of monetary policy, business cycles can be formed when government forces interest rates below their natural market level, stimulating artificial development of capital industries (Mises 2008). In addition, consumption will also be stimulated as individuals are incentivized to spend more and save less. When spending on both capital and consumption goods is stimulated by the government, a tug-of-war competition for scarce resources ensues (Garrison 2001).

The first phase of the cycle is the boom that is a result of the dualstimulus spending on capital and consumer goods. A euphoria of prosperity will prevail (Mises 2011, 564). The new artificially lower 
interest rate through credit expansion drives GDP growth. Capital and consumer projects are implemented, with the former being more sensitive to interest-rate manipulation and credit expansion. Thus, capital projects begin growing at a higher rate than consumer projects (Hayek 2008).

Eventually the economy does not have all the resources to complete all the projects that are being simultaneously pursued. On the one hand, qualified labor and land are scarce resources and simultaneous competition for them will lead to rising prices in the factors of production (Garrison 2001, 72). On the other hand, capital is also a scarce resource and, when purchased with newly created money, its price rises quickly as well (Mises 2008, 550).

As a consequence of this process, nominal interest rates eventually rise because of future real losses in the value of bank loans because of inflation. ${ }^{4}$ The expected result is that capital goods will suffer disproportionately from the early reversal of this process (Mises 2008). In addition, the consumer-goods industry will also suffer from the decrease in the purchasing power of money imposed by inflation. A recession will follow and pessimistic expectations in the market will turn projects once deemed profitable into malinvestments (Rothbard 2009, Holcombe 2017). Banks will then tend to impose greater restrictions on lending because of negative expectations for the economy. The result is stagnation or a fall in credit expansion (Mises 2008, 565).

$\mathrm{ABCT}$ is concerned with artificially low interest rates driving not only malinvestment, but overconsumption in the inflationary boom portion of the business cycle (Mises 2008, Rothbard 2000, Hayek 2008). Its essence is the falsification of monetary calculation; it is not an overinvestment ("hydraulic") theory of business cycles as misunderstood by a pantheon of mainstream macroeconomists from Paul Krugman and Brad DeLong to Tyler Cowen and Bryan Caplan (Salerno 2012).

When the inevitable macroeconomic bust arrives, a return to the old conditions begins through gradual market adjustments.

\footnotetext{
${ }^{4}$ This will necessitate the addition of an inflation premium onto the real interest rate to compensate for the fall in the purchasing power of the currency unit. The sum of the real interest rate plus the inflation premium is the nominal interest rate.
} 
The recession is the "healthy" phase in which the economy begins recovering if the government bows out. If the government does not cease its interventions, the recovery will stall and the recession will continue (Rothbard 2009). In summary, the recession phase is characterized by a fall in prices, a rise in the interest rate, consumer thrift, and slow sales for entrepreneurs.

\section{METHODOLOGY}

Economic cycles occur within a period of time and in a specific geographic region. The recent cycle in Brazil occurred in three distinct phases, covering a period of approximately 13 years (2004-16) from boom to bust. GDP was used to provide a general measure of macroeconomic performance. If $\mathrm{ABCT}$ explains the boom and bust caused by a cluster of errors (Hülsmann 1998), then those errors will affect GDP positively and negatively during the business cycle. For that reason, the main criteria for distinguishing the cyclical phases were fluctuations in GDP, interest rates, credit expansion, industrial production of consumer and capital goods, and macroeconomic policy enacted by Brazil's government.

After identifying the phases of the cycle, the macroeconomic variables of relevance were collated. They are as follows:

1. GDP

2. interest rate

3. money supply

4. credit expansion

5. savings

6. industrial production (higher-order stages)

7. industrial production (lower-order stages)

8. inflation

GDP of course provides a big picture view of when the crisis unfolded and why the recent cycle was the most severe in Brazil's more-than-one-hundred years of history. It will be displayed on an annual basis. Obviously, it is expected to grow in the boom phase and fall in the bust phase. 
The second variable, the real interest rate, is key for tracing credit expansion and how this expansion lead to an unsustainable boom. The expected results would be a fall in the interest rate during the boom and a rise during the bust. The third variable, Brazilian monetary aggregate M2, will track the changes in the Brazilian money supply. ${ }^{5}$ We expect that this variable will grow during the boom and stagnate or decline in the bust. As for credit expansion, the fourth variable, the expected results are an expansion during the boom and a stagnation or decline during the bust.

As for nominal savings (fifth variable), there is no particular expectation about its direction in either the boom or bust phases. If there is an increase in its size during the boom, it must be less than that of artificial credit expansion.

For the sixth and seventh variables, as explained in the previous section, higher-order goods experience a higher rate of growth than lower-order goods during booms. When the bust arrives, higher-order goods production will decline at a higher rate than lower-order goods production. Capital (higher order) goods tend to have more volatile production levels than consumer (lower order) goods. In the nomenclature of statistics, capital-goods production levels have a higher standard deviation from the mean (Rothbard 2009, 19).

Finally, inflation (eighth variable) will tend to rise in the boom phase, since both capital and consumer goods are receiving major stimuli, and this in turn puts pressure on the prices of the factors of production. After first flowing into capital goods, new money raises demand downstream and eventually puts pressure on the prices of consumer goods (Hayek 2008). There must be an eventual reversal of the growth of inflation in the bust phase or a steep fall in it when adjustments instantiate into inflated prices.

Table 1 below is a summary of expected results in the variables during the boom and bust periods. As can be seen in the table, in some cases the theory does not predict any particular result.

\footnotetext{
${ }^{5}$ In Brazil, M2 is defined as it is in the U.S.: currency (coins and bills) + demand deposits + traveler's checks + other checkable deposits + savings deposits + small time deposits + money-market mutual funds + some minor categories (Mankiw 2018, 324).
} 


\section{Table 1. Expected Results (ABCT)}

\begin{tabular}{|c|c|c|c|}
\hline Variable & $\begin{array}{l}\text { Macro Tripod } \\
\text { Boom or } \\
\text { T-Boom } \\
\text { (Phase 1) }\end{array}$ & $\begin{array}{l}\text { Reset and New } \\
\text { Economic Matrix } \\
\text { Boom or M-Boom } \\
\text { (Phase 2) }\end{array}$ & $\begin{array}{l}\text { Bust } \\
\text { (Phase 3) }\end{array}$ \\
\hline 1 GDP & \multicolumn{2}{|c|}{$\begin{array}{l}\text { Rises } \\
\text { (Mises 2008, 610). }\end{array}$} & $\begin{array}{l}\text { Falls } \\
\text { (Mises 2008, 610). }\end{array}$ \\
\hline 2 Interest rate & \multicolumn{2}{|c|}{$\begin{array}{l}\text { Falls } \\
\text { (Garrison 2001, 69). }\end{array}$} & $\begin{array}{l}\begin{array}{l}\text { Rises } \\
\text { (Garrison 2001, 72). }\end{array} \\
\end{array}$ \\
\hline $\begin{array}{l}3 \text { Money } \\
\text { supply }\end{array}$ & \multicolumn{2}{|c|}{\begin{tabular}{|l|}
$\begin{array}{l}\text { Rises } \\
\text { (Haberler 1983, 9). }\end{array}$ \\
\end{tabular}} & \begin{tabular}{|l|}
$\begin{array}{l}\text { Levels out or falls } \\
\text { (Haberler 1983, 9). }\end{array}$ \\
\end{tabular} \\
\hline 4 Credit & \multicolumn{2}{|c|}{\begin{tabular}{|l}
$\begin{array}{l}\text { Rises } \\
\text { (Mises 2008, 549). }\end{array}$ \\
\end{tabular}} & \begin{tabular}{|l|}
$\begin{array}{l}\text { Falls } \\
\text { (Mises 2008, 565). }\end{array}$ \\
\end{tabular} \\
\hline 5 Savings & \multicolumn{2}{|c|}{$\begin{array}{l}\text { Stagnates, falls, or } \\
\text { rises less than credit expansion } \\
\text { (Garrison 2001, 70).* }\end{array}$} & No prediction. \\
\hline $\begin{array}{l}6 \text { Industrial } \\
\text { production } \\
\text { for higher } \\
\text { orders } \\
\end{array}$ & \multicolumn{2}{|c|}{$\begin{array}{l}\text { Rises more than lower orders } \\
\text { (Rothbard 2009, 19-20). }\end{array}$} & $\begin{array}{l}\text { Falls more than lower orders } \\
\text { (Rothbard 2009, 19-20). }\end{array}$ \\
\hline $\begin{array}{l}7 \text { Industrial } \\
\text { production } \\
\text { for lower } \\
\text { orders }\end{array}$ & \multicolumn{2}{|c|}{$\begin{array}{l}\text { Rises less than higher orders } \\
\text { (Rothbard 2009, 19-20). }\end{array}$} & $\begin{array}{l}\text { Falls less than higher orders } \\
\text { (Rothbard 2009, 19-20). }\end{array}$ \\
\hline 8 Inflation & \multicolumn{2}{|c|}{$\begin{array}{l}\text { Rises } \\
\text { (Mises 2008, 550). }\end{array}$} & $\begin{array}{l}\text { Levels out or falls } \\
\text { (Mises 2008, 566). }\end{array}$ \\
\hline
\end{tabular}

* No explicit prediction for this was found in $\mathrm{ABCT}$ but was deduced from the theory of Garrison (2001) in which it is impossible to have growth in credit markets when savings falls except in the case of government intervention.

In later sections of this article, these results predicted by $\mathrm{ABCT}$ will be compared to the actual ones from the 2004-16 Brazilian cycle. The methodology used in this study does not involve an empirical test in the sense that hypotheses were formed and-or extraneous economic models were used to test ABCT (Hoppe 2007). The authors only wish to observe whether results consistent with $\mathrm{ABCT}$ occurred, assuming that no other exogenous variable(s) significantly influenced these results. Thus if a few of the observed results are not compatible with the theory, it does not necessarily mean that the theory has been refuted but rather that other variables not included in the present study may have affected the results. 
Industrial production was disaggregated into specific sectors and how they behaved in the various phases of the cycle. These phases were categorized in light of the structure of production illustrated in Hayek's triangle (Hayek 2008). The more distant from consumer goods (higher orders), the more capital intensive and time consuming the process becomes. The opposite is also true: businesses closer to consumer goods (lower orders) are less capital intensive and less time consuming. Some industries are not clear cut. For example, the construction sector has characteristics of both orders: it is close to the consumer in some transactions, absorbs significant time and capital to produce certain products in other transactions, and is very interest-rate sensitive. On balance, this sector will be classified as higher order. The data used are from the Brazilian Institute of Geography and Statistics (Instituto Brasileiro de Geografia e Estatística, or IBGE for short) and the Central Bank of Brazil (Banco Central do Brasil, or BCB for short). Both of these institutions in Brazil are (not surprisingly) government agencies. Their classifications were used and then macroeconomic sectors were designated as higher-, intermediary-, or lower-order as shown in Table 2 below. 
Table 2. Classification of Brazil's Industrial-Production Statistical Series* by Their Location in the Brazilian Structure of Production

\begin{tabular}{|l|l|l|}
\hline $\begin{array}{l}\text { Central Bank Series } \\
(\mathbf{2 1 8 6 1 - 2 1 8 6 8 )}\end{array}$ & $\begin{array}{l}\text { Location in } \\
\text { Production Structure }\end{array}$ & Sector \\
\hline 21861 & Higher order & Mineral \\
\hline $21868^{* *}$ & Higher order & Construction \\
\hline 21866 & Higher order & Durables \\
\hline 21863 & Higher order & Capital goods \\
\hline 21864 & Intermediary & Intermediaries \\
\hline 21862 & Intermediary & Transformation industry \\
\hline 21865 & Lower order & Consumer \\
\hline 21867 & Lower order & Semi- and non-durable goods \\
\hline 21859 & - & General (all sectors together) \\
\hline
\end{tabular}

Source: BCB Industrial Production series 21861-68.

* See methodological notes (Brazilian Institute of Geography and Statistics 2004).

** This series became available in January 2012, therefore analysis will be limited.

Again, despite the fact that some authors have attempted to empirically test ABCT (e.g., Luther and Cohen 2014), this study will only analyze data in light of ABCT. The authors included changes in savings and interest rates in their criteria for defining the different phases of the cycle (Garrison 2006).

\section{THE BRAZILIAN EXPERIENCE}

When President Lula took office in 2003, many supporters and opponents of his Workers Party (Partido dos Trabalhadores, or PT for short) were expecting that Lula would implement the agenda that PT had been preaching for several years. Since the 1990s, PT was mainly against "everything that was out there," advocating market-unfriendly policies (Leitão 2011, 396 [authors' translation]). With a radical-left mindset, members of the party and Brazilians in general thought that an agenda of economic intervention, such as debt default, would be enacted by the new president (Giambiagi et al. 2016, 198).

Markets were expecting a departure from the economic regime of Lula's predecessor, Fernando Henrique Cardoso. The Cardoso 
administration was in compliance with International Monetary Fund (IMF) recommendations and its economic policies were christened the Macroeconomic Tripod. The Tripod, per its name, was based on three major goals: fiscal austerity, inflation control, and a floating exchange rate (Veloso et al. 2013).

However, Lula unexpectedly embraced the Macro Tripod and continued with it in his first term, which ran from 2003 to 2006 (Amorim 2016, 28). Macro-economically, the year 2003 was very turbulent for Brazil because markets were expecting an abandonment of the Tripod. The following year, 2004, is when the first continuous boom of the cycle began.

Suggested proximate causes outside of those specified in ABCT include the following. First, loose money policies in the major world economies allegedly triggered large capital inflows into Brazil. Two BCB officials (Hennings and Mesquita 2008) demonstrate that foreign direct investment (FDI), after reaching a peak of around $\$ 40$ billion (U.S.) in 2001, fell to about half that in late 2003, then began strongly surging again after mid-2004, reaching around $\$ 60$ billion (U.S.) in early 2008. Local equity market inflows surged from $\$ 5.4$ billion (U.S.) in 2005 to $\$ 24.6$ billion (U.S.) by 2007. In this exact same time interval, gross inflows surged from $\$ 32.3$ billion (U.S.) to $\$ 116.6$ billion (U.S.). "[N]et or gross terms, these inflows are unprecedented in the post-World War II Brazilian experience" (Hennings and Mesquita 2008, 107).

Second, BCB increased the money supply in Brazil. Third and last, government fiscal and regulatory policy added more fuel to the boom. One alleged example is a September 2003 executive order (later legislatively approved in December 2003) that authorized banks to offer loans that could be repaid through automatic payroll deductions. A study by Coelho, Mello, and Funchal (2010) found that the new law caused a significant decline in interest rates and significant increase in credit. ${ }^{6}$

Brazil's economic cycle will be divided into three phases. Phase 1 is the continuance of the Macroeconomic Tripod (T-boom for short) by President Lula throughout his first full term and half of his

\footnotetext{
${ }^{6}$ The authors do not necessarily agree with these purported extra-ABCT causes. A planned follow-up study will explore this issue in greater detail.
} 
second term, the years 2004-08 in which the boom began. President Lula's first year in office was 2003, but that year was removed from this study because, as previously mentioned, it was a period of great instability which clouds the analysis.

The financial crisis in the United States which peaked in September $2008^{7}$ with the failure of Lehman Brothers investment bank was the trigger that shifted the Lula administration away from the Macro Tripod. The administration's new model, later named the New Economic Matrix, was based on five major pillars:

1. Aggressive reduction of interest rates.

2. Credit expansion to consumers and private enterprises through publicly owned commercial and development banks.

3. Government privileges for boosting specific private companies.

4. Subsidies and fiscal abnegation for specific sectors to boost the economy.

5. State enterprises controlling prices and inflation. ${ }^{8}$

Even though all of the aforementioned interventions played a part in causing the boom and bust, this study will argue that the main causes were artificially low interest rates and accompanying credit expansion and that all other interventions were secondary in nature.

Lula's shift between economic models will be referred to as "Reset" in this paper, an allusion to the old mindset of PT, which advocates major government interventions to steer Brazil's economy. This second stage of Lula's economic program contains the Reset and Economic-Matrix boom or M-boom. In other words, this paper divided the boom periods of the cycle into two parts: T-boom (Phase 1) and Reset plus M-boom (Phase 2).

Finally, the last phase (Phase 3) is the bust. Brazil's economy shrank for 11 consecutive quarters, producing the worst crisis in the nation's history. The second leg of the "flight of the chicken"

\footnotetext{
${ }^{7}$ While the initial tremors of the crisis were felt in the bank runs against BNP Paribas (9 August 2007) and Northern Rock (14 September 2007), the apex of the crisis was undoubtedly the collapse of Lehman Brothers on 15 September 2008.

${ }^{8}$ This economic plan was gradually being implemented and refined over some years, starting in 2008 and taking full form by 2011. For a timeline of this economic plan and its main pillars, see Roque (2015).
} 
lasted five years (2010-14) before the economy nosedived into the dark waters of deep recession.

In Figure 1 below, the blue bars evince economic growth for 2004-14. The years 2004-08 delivered a mean of 4.81 percent annual growth. The year 2009 represented mainly stagnation for the Brazilian economy. Between 2010 and the beginning of 2013, annual growth was 4.1 percent. While this Matrix-boom average is lower, it is still close to that of the T-boom phase. In the last phase (bust), there was a deep recession with 3.8- and 3.6-percent negative growth in 2015 and 2016, respectively. What is not shown in Figure 1 below is that the recession ended in the first quarter of 2017 with a positive quarterly growth rate in GDP of one percent.

\section{Figure 1. Average Annual Growth Rate in GDP Across Brazil's 2004-16 Business Cycle}

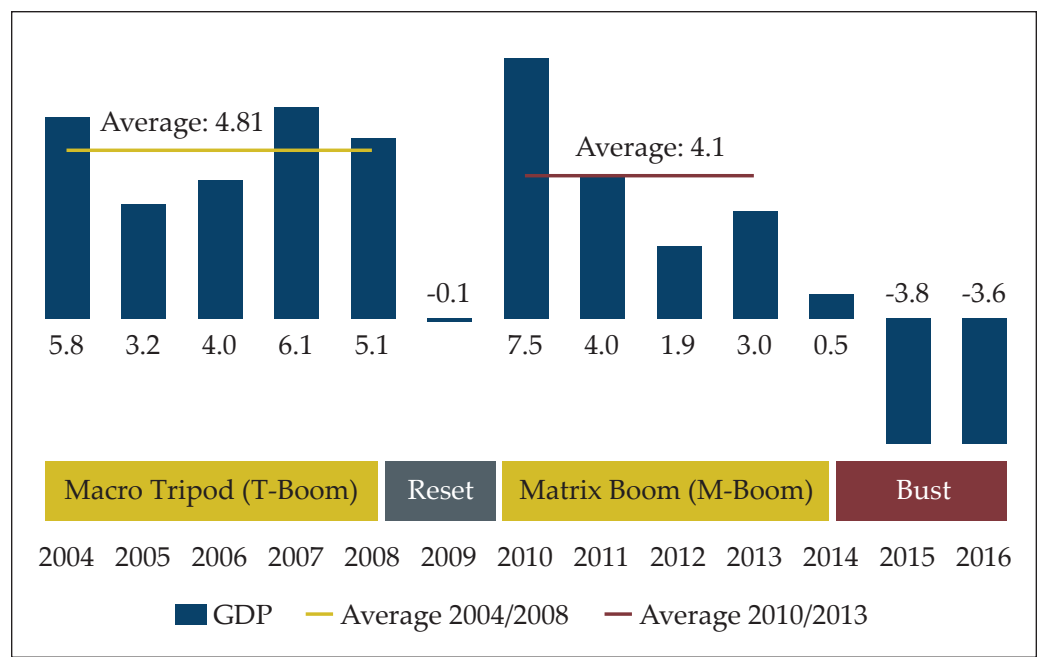

Source: Central Bank of Brazil GDP series 7326.

For the purposes of this article, it will be assumed that the Reset began after the peak of the U.S. financial crisis in September 2008 and ended at the end of 2009. The M-boom began in about January 2010 and ended in approximately February 2014. These dates are estimates because it is difficult to pinpoint with great precision when 
the boom and bust phases began and ended. The great precision that is lost is not relevant for the purposes of this paper. In some cases, only full years will be analyzed-the specific months that characterize each phase will be dismissed. Table 3 below specifies in detail the approximate boundaries of each phase.

Table 3. Components of the Brazilian Business Cycle (2004-16)

\begin{tabular}{|l|l|l|l|}
\hline Phase & $\begin{array}{l}\text { Stage of } \\
\text { Business Cycle }\end{array}$ & Label & Time Period \\
\hline 1 & Boom (Phase 1) & $\begin{array}{l}\text { Macro-Tripod } \\
\text { Boom or T-boom }\end{array}$ & T-boom: Jan. 2004-Sep. 2008 \\
\hline 2 & Boom (Phase 2) & $\begin{array}{l}\text { Economic-Matrix } \\
\text { Boom or M-boom }\end{array}$ & $\begin{array}{l}\text { Reset: Oct. 2008-Dec. 2009 } \\
\text { M-boom: Jan. 2010-Feb. 2014 }\end{array}$ \\
\hline 3 & Bust (Phase 3) & Recession (Bust) & Bust: Mar. 2014-Dec. 2016 \\
\hline
\end{tabular}

\section{V.PHASES 1 AND 2: T-BOOM, RESET, AND M-BOOM}

One of the most important aspects of $\mathrm{ABCT}$ is the manipulation of the interest rate by the central bank. Figure 2 below illustrates real annual interest rates throughout Brazil's recent cycle. In the first phase of the cycle (2004-08), the real interest rate averaged 9.18 percent per annum. During the second phase-Reset and M-boom-between 2009 and 2013, the mean real interest rate was 3.91 percent. ${ }^{9}$ This is a difference of 5.27 percentage points, or a fall of about 57 percent. Throughout the bust, the real annual interest rate fell no lower than 4 percent.

\footnotetext{
${ }^{9}$ Special System of Liquidation and Custody (Sistema Especial de Liquidação e Custódia, SELIC for short) is the system used by the Central Bank of Brazil (BCB) to implement its interest-rate policy via buying and selling government bonds.
} 


\section{Figure 2. Five-Year Average of Annual Real Interest Rates in Brazil (2004-08, 2009-13)}

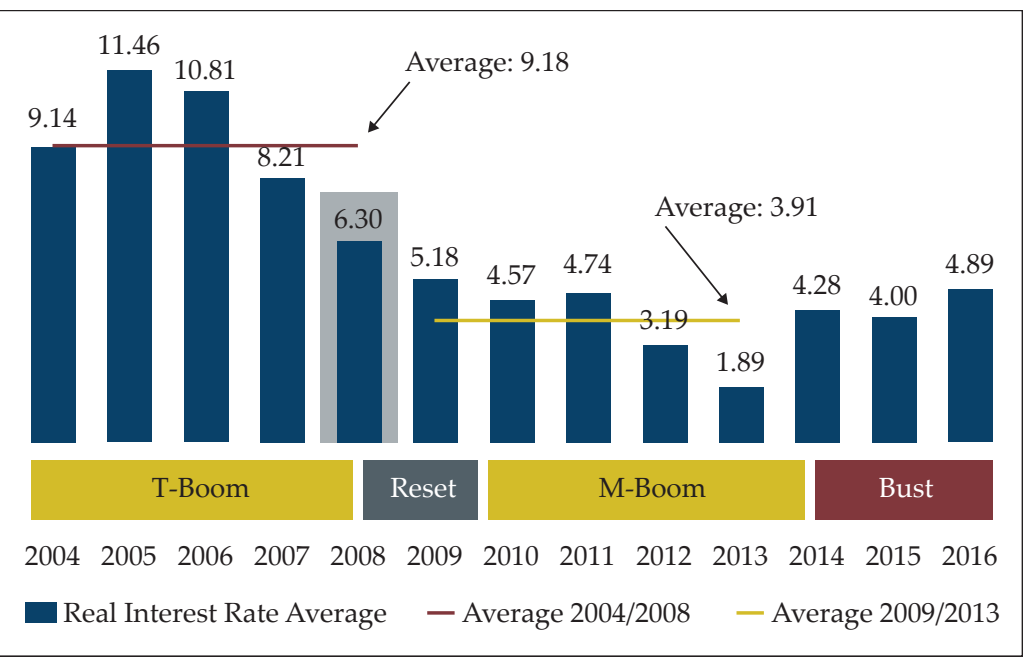

Source: Central Bank of Brazil (BCB). SELIC series 4390. For the real interest rate calculation authors used Fisher equation. For the nominal rate, authors used annualized SELIC rate and for the inflation rate authors used the IPCA 12-month inflation index for each month. The blue bars represent the average for the year.

Recall that when the interest rate falls, the demands for both capital goods and consumer goods will be stimulated (Garrison 2001, 72). If the interest rate fell between the first two phases, this would lead us to expect that credit offered to businesses and consumers would enjoy strong and continued growth between the two periods.

It is interesting to note the behavior of M2 surrounding the reduction in the interest rate. Table 4 displays the compound-adjusted growth in M2 in each phase. 
Table 4. Compound Average Growth for M1 and M2

\begin{tabular}{|l|l|l|l|l|l|}
\hline Phase & $\begin{array}{l}\text { Stage of } \\
\text { Business Cycle }\end{array}$ & Time Period & $\begin{array}{l}\text { CAG } \\
\text { M1 }\end{array}$ & $\begin{array}{l}\text { CAG } \\
\text { M2 }\end{array}$ & $\begin{array}{l}\text { M2 Average } \\
\text { (Phase 2 Only) }\end{array}$ \\
\hline \multirow{2}{*}{2} & T-boom & Jan. 2004 - Sep. 2008 & $15.34 \%$ & $20.83 \%$ & \\
\cline { 2 - 5 } & Reset & Oct. 2008 - Dec. 2009 & $24.52 \%$ & $12.15 \%$ & $12.93 \%$ \\
\cline { 2 - 4 } & M-boom & Jan. 2010 - Feb. 2014 & $8.54 \%$ & $13.71 \%$ & \\
\hline \multirow{2}{*}{3} & Bust & Mar. 2014 - Dec. 2016 & $4.43 \%$ & $7.27 \%$ & \\
\hline
\end{tabular}

Source: Central Bank of Brazil (BCB). M1 and M2 series 27791 and 27819, respectively.

It is clear that the boom period had an outstanding growth rate in M2 of 20.83 percent in Phase 1 and 12.98 percent in Phase 2. Before analyzing the results, it is important to make an observation about credit markets in Brazil. Brazil's credit markets are divided by the Brazilian central bank as follows: government-supported credit policies (code 7524); "free-market" credit for businesses (code 12128), and "free market" credit for consumers (code 12127). ${ }^{10}$ The first category, credit supported by government policies, includes loans through state agencies such as the National Bank for Economic and Social Development (Banco Nacional de Desenvolvimento Econômico e Social, BNDES for short), which offers subsidized or policy-oriented credit to sectors chosen by the government. The second category, "free-market" credit, includes all credit that is offered by banks to businesses and consumers. It should come as no surprise that the entire Brazilian credit market is subject to significant government control. Between 2004 and 2012, the average government share in total credit was 34 percent. ${ }^{11}$

Figure 3 shows the growth of credit in the first two phases of the cycle. Displayed in the left panel of Figure 3 is the growth pattern of business credit. It is composed of government and free market credit for businesses. The average annual compound growth rate was 22 and 16 percent for Phases 1 and 2, respectively. Displayed in the right

\footnotetext{
${ }^{10}$ If one wants to see the combined series for "free-market" credit (businesses and consumers), the code is 12130 .

${ }^{11}$ For this calculation, the authors used the last month of each year (December) for government credit (code 7524) divided by total credit in the period (the sum of total government credit [code 7524] and "free-market" credit [code 12130]).
} 
panel of Figure 3 is the growth pattern of credit for individuals. Note that the growth of credit to individuals is even higher than the growth of credit to businesses in Phase 1, reaching 27 percent. In Phase 2, there is an impressive 20 percent rate of continued growth in credit to individuals. Interestingly, the growth rates of credit in Phase 1 for both graphs (22 and 27 percent) are higher than their counterparts in Phase 2 (16 and 20 percent).

As alluded to in the previous section, certain factors unquestionably drove this credit expansion. In terms of alleged causes not specified by $A B C T$, one suggestion is that loose money policies in the major world economies directed large capital flows into Brazil. No matter how they are measured — net or gross—-the inflows were unrivalled in the post-World War II history of Brazil (Hennings and Mesquita 2008, 107). Government fiscal and regulatory policy added more stimulation. One alleged example is an executive order authorizing banks to offer loans repayable through payroll deductions. This "innovation" significantly expanded credit (Coelho, Mello, and Funchal 2010). ${ }^{12}$

${ }^{12}$ Again, the authors do not necessarily agree on all of these purported extra-ABCT causes. A planned follow-up study will explore this issue in greater detail. 


\section{Figure 3. Credit Expansion for Businesses and Individuals (in billions R\$)}

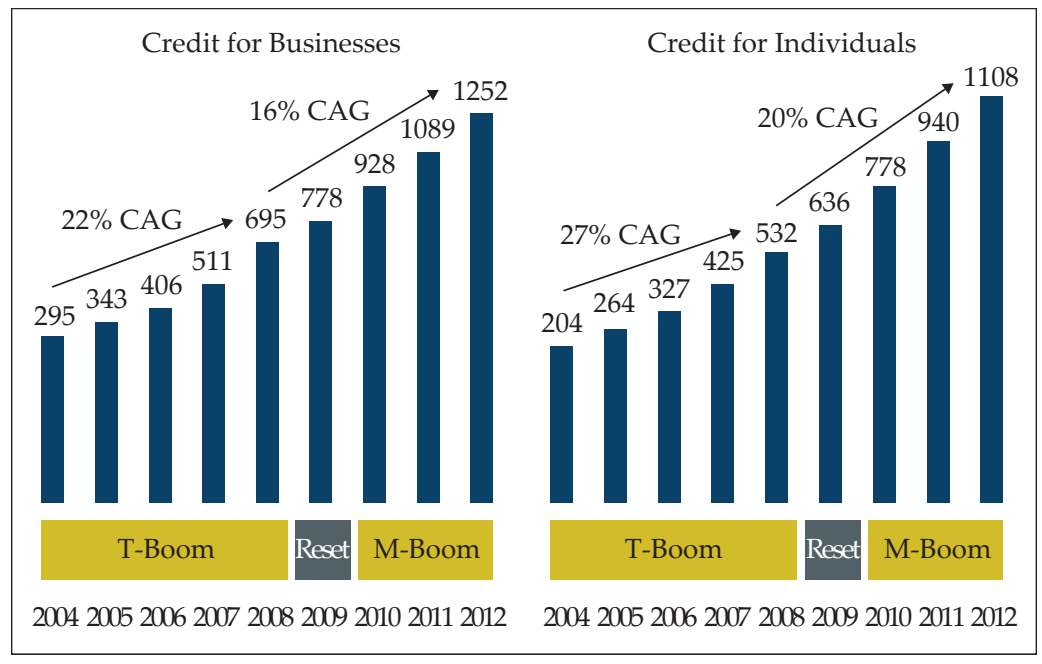

Source: Data from BCB (Brazilian Central Bank), elaborated by authors. Business credit series is a result of the sum of government credit policies for business (code 20021) with free market credit for business (code 12128). For individuals, it was calculated by the sum of government credit policies for individuals (code 20020) with free market credit for individuals (code 12127). It used December of each year as a basis for this calculation. For the calculation of compound average growth (CAG) in 2004, it used December 2003 as a starting point. Those series were discontinued and were only available until 2012, which means that the second phase will have a year less.

A fall in interest rates would not be a problem per se, provided that it was driven by voluntary savings on the part of individuals (Hayek 1931). When individuals increase their savings, interest rates fall and funds flow to capital goods. When this route is followed, the time preferences of consumers can be synchronized with those of entrepreneurs who want to engage in new projects (Manish and Powell 2014). As a consequence, savings behavior during the recent Brazilian cycle must be analyzed to determine whether Brazil's massive credit expansion was caused by a natural increase in voluntary savings or artificial state actions. 
The next figure, Figure 4, juxtaposes the average growth rate of savings with the interest rate. ${ }^{13}$ In the first phase of the cycle (2004-08), the average annual growth of savings was 2.2 percent of GDP, rising from 15.3 percent (at the end of 2003) to 16.9 percent of GDP. However, the interest rate fell an average of 10.7 percent per annum. Its range was between 11.25 percent and 19.75 percent, with an average of 15.07 percent. In other words, the first phase was characterized by a large reduction in interest rates coupled with a relatively low growth rate in savings, as can be seen in the two bars on the left-hand side of Figure 4 below.

\section{Figure 4. Average Annual Growth of Savings and Interest Rate}

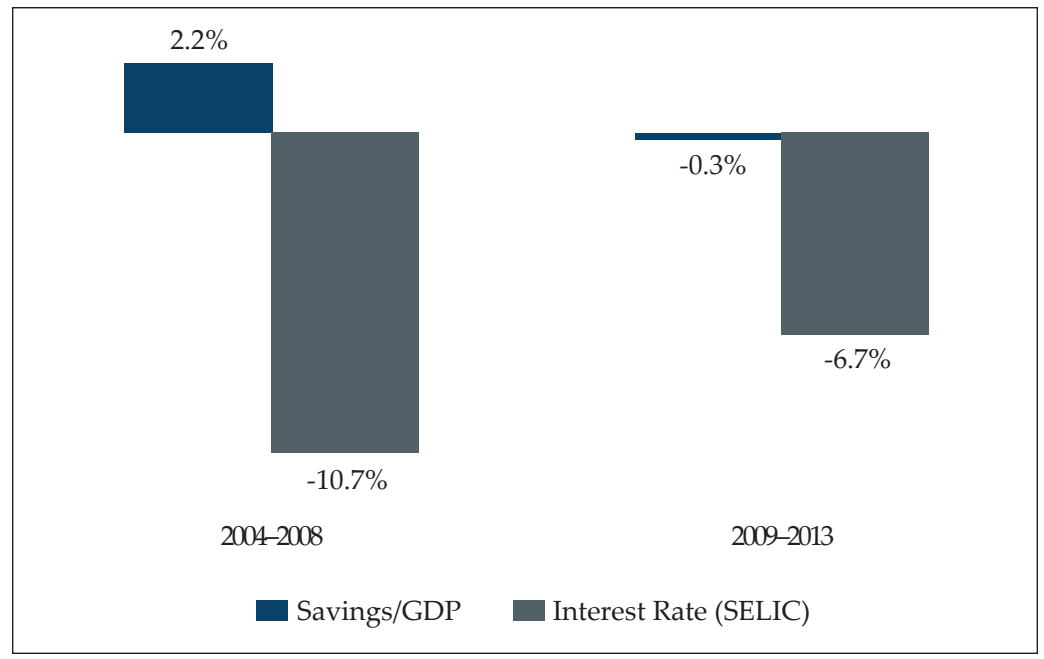

Source: World Bank and Brazilian Central Bank data, elaborated by authors. Interest Rate (SELIC) series: 4390.

Table 5 below summarizes what happened to interest rates, savings, and monetary and credit expansion in Phase 1 and Phase 2. Phase 1 had a nominal average interest rate of 15.08 percent while Phase 2 had a nominal average rate of 9.77 percent, a fall of 35 percent. The average real interest rate for Phase 1 was 9.18 percent,

\footnotetext{
${ }^{13}$ For the 2004 savings-growth statistic, the authors used the 2003 statistic (15.3 percent of GDP) as the basis (World Bank 2018).
} 
while for Phase 2 it was 3.91 percent. In terms of savings, Phase 1 had an annual growth rate of 2.2 percent while Phase 2 had an annual growth rate of -0.3 percent.

Table 5. Interest Rates, Money, Credit, and Savings (Consolidated Results)

\begin{tabular}{|l|l|l|}
\hline Variable & $\begin{array}{l}\text { T-Boom } \\
\text { 2004-08 } \\
\text { Phase 1 }\end{array}$ & $\begin{array}{l}\text { Reset + M-Boom } \\
\mathbf{2 0 0 9 - 1 3} \\
\text { Phase 2 }\end{array}$ \\
\hline Average nominal interest rate & $15.08 \%$ & $9.77 \%$ \\
\hline Maximum nominal interest rate & $19.13 \%$ & $11.69 \%$ \\
\hline Minimum nominal interest rate & $12.15 \%$ & $8.21 \%$ \\
\hline Average real interest rate & $9.18 \%$ & $3.91 \%$ \\
\hline M1 (CAG) & $15.34 \%$ & $16.53 \%^{*}$ \\
\hline M2 (CAG) & $20.83 \%$ & $12.93 \%^{*}$ \\
\hline Credit for businesses (CAG) & $22 \%$ & $16 \%$ \\
\hline Credit for individuals (CAG) & $27 \%$ & $20 \%$ \\
\hline Average annual growth of savings (portion of GDP) & $2.2 \%$ & $-0.3 \%$ \\
\hline
\end{tabular}

*Average for Phase 2 (Reset + M-Boom)

It is reasonable to conclude that the consistent fall in the interest rate in both phases was not driven by an increase in voluntary savings. In fact, in the second phase, there was a decline in savings. The decline in the interest rate and increase in credit had a huge impact on credit expansion for businesses and individuals, which in turn caused a significant distortion in the structure of production as explained in the next section.

\section{Central-Bank Control of the Interest Rate and Its Impact on Higher and Lower Orders of Production}

To analyze the impact on the structure of production, we explored Phase 2 and 3 in greater depth. The structure of production was gradually changing in Phase 1 and started undergoing a complete distortion in Phase 2. As a result, the authors dedicated more analysis to this distortion that occurred in Phases 2 and 3. 
The impact of lowering interest rates in the absence of voluntary savings will be different within higher and lower orders of production (Hayek 2008). In the terminology of statistical analysis, higher orders of production have a higher standard deviation in production levels than lower orders of production (Rothbard 2000, 9).

The results are consistent with ABCT. Recall that these results were elucidated earlier in the methodology section of this article for all sectors for which it was possible to obtain industrial-production data: Mineral, Intermediaries, Semi- and Non-durables, etc. Table 6 below displays the standard deviations of these sectors through Phase 2 and Phase 3. Standard deviations and the averages for each sector were then calculated.

Table 6. Industrial-Production Volatility for Phase 2 (Reset and M-Boom) and Phase 3 (Bust)

\begin{tabular}{|l|l|l|l|l|}
\hline Production Stage & Sector & STD DEV & MAX & MIN \\
\hline Higher order & Minerals & 8.06 & 115.00 & 71.80 \\
\hline Intermediary & Intermediaries & 8.50 & 111.40 & 75.80 \\
\hline Lower order & Semi- and Non-Durables & 8.46 & 116.00 & 78.70 \\
\hline- & General $^{*}$ & 9.21 & 112.60 & 75.80 \\
\hline Lower order & Consumer $^{-1}$ & 9.56 & 116.30 & 75.50 \\
\hline Intermediary & Transformation & 9.88 & 113.70 & 73.70 \\
\hline Higher order & Construction & 12.24 & 110.90 & 61.10 \\
\hline Higher order & Durables & 16.73 & 119.30 & 54.70 \\
\hline Higher order & Capital Goods & 18.29 & 127.10 & 51.60 \\
\hline
\end{tabular}

* All sectors included.

To calculate the average standard deviation, two extreme values were eliminated from the data set (Minerals and Capital Goods). The average standard deviation of all sectors is 10.65 . Figure 5 below reveals that three sectors of the economy were above average: Construction, Durables, and Capital Goods. These three sectors were clearly the most volatile and received the most impact from central-bank stimuli. They represent 75 percent of the higher-order sectors.

The data for the Construction series became available in January 2012 - in the middle of the M-boom — which means that the actual 
standard deviation could be much greater than the recorded values indicate. This of course would have represented even stronger confirmation of ABCT.

\section{Figure 5. Standard Deviation of Industrial Production Among Sectors for Phases 2 and 3 (Sep. 2008 to Dec. 2016)}

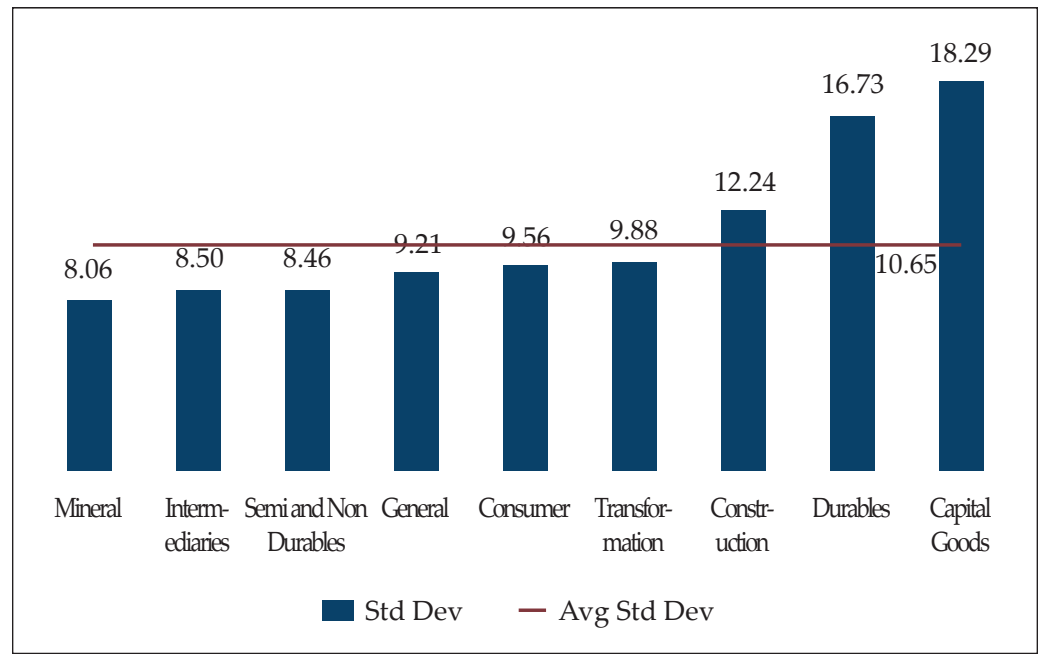

Source: Central Bank of Brazil (BCB).

One notable exception in the data was the mineral sector, clearly an industry belonging to the higher-order category. In Brazil, this industry has a large portion of its production in two main sub-sectors: iron ore and petroleum and natural gas (and its byproducts). For the iron-ore subsector, it is very well known that one of the most important markets is exports, and for that reason it is very sensitive to international-market conditions. In 2014, about 86 percent of Brazil's iron-ore production was exported. In 2016, Vale (one of the largest iron-ore producers in the world) achieved a new production record which stood in stark contrast to the contraction witnessed in the other higher-order sectors (Construction, Durables, and Capital Goods) during the recession (Rosas and Machado 2017). Hence, iron ore is not synchronized with the internal Brazilian business cycle and thus of little relevance to this study. 
As for petroleum and natural gas, the main supplier of those products is the state-controlled company Petrobras, one of the largest oil companies in the world. This sector is subject to heavy government intervention, thus central planning, not free markets, guides much of its decision making. During the boom, the government prevented the company from raising prices in an attempt to control inflation, even at the cost of significant losses ("Petrobras Approves New Fuel Price Readjustment Policy," 2013). Such strong state influence muddles the analysis, since the government could accumulate large losses without compromising production.

Taking the long view, the standard deviation, from January 2004 to December 2016, is 10.64. In other words, the standard deviation converges to the average of other sectors. This is not the case for the capital-goods sector which over the same time span had a standard deviation of 18.27: almost identical to the present results. The fact that the petroleum and natural-gas sector is so extensively state controlled makes it almost certain that production decisions were influenced by political considerations rather than sound market fundamentals. This undoubtedly led to distortions in output.

In sum, the results show that Brazil's higher-order sectors experienced the highest growth in the M-boom and the steepest fall in the bust phase compared to lower-order sectors of production. These results are consistent with ABCT. The Mineral sector is an anomaly because of its atypical export dependence in iron ore. The Petroleum and Natural Gas sector is another outlier because extensive government controls guide its production decisions.

\section{Capital and Consumer Goods: A Closer Look}

In Phase 1, industrial production for capital and consumer goods was relatively low in 2003, with index values of 50 and 68 (base year $2012=100$ ), respectively. Figure 6 below reveals that both had tremendous growth in subsequent years until this growth was interrupted by the peak of the U.S. financial crisis in September 2008. After this interruption, growth fell precipitously until about the end of the first quarter of 2009. From January 2003 (50.9) to October 2008 (124.8) to February 2009 (73.4), capital goods rose 145 percent to a high and fell 41 percent to a low. From February 2003 
(68.1) to October 2008 (110.3) to February 2009 (77.3), consumer goods rose 62 percent to a high and fell 30 percent to a low.

\section{Figure 6. Industrial Production of Capital and Consumer Goods Indices (Base Year $2012=100$ )}

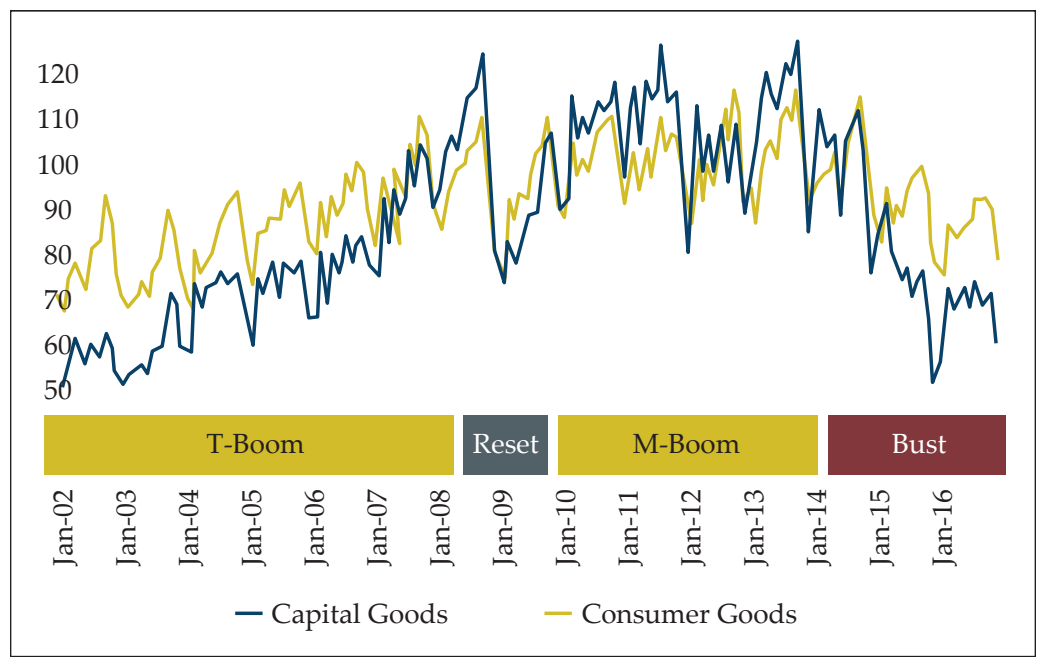

Source: Central Bank of Brazil (BCB). Capital-goods series 21863. Consumer goods series 21865.

After the Reset, the government began to suppress interest rates with the aim of stimulating the economy, going so far as to even threaten private banks to get on board the program ("On TV, Dilma Raises Tone to Private Banks and Asks Interest Cut," 2012). The effects of this in terms of greater relative capital-goods volatility can be seen very clearly in Figure 7 below, which shows industrial-production index differences (capital goods minus consumer goods). Where the blue bars in the aforementioned figure indicate negative values, the capital-goods index was less than the consumer-goods index (see scale values on the right vertical axis of Figure 7 ). The inverse is also true.

Note that in Phase 1 (2004-08), capital-goods production exceeded consumer-goods production for only ten months of the 60-month Phase-1 period. In contrast, during the 2009-13 period (Phase $2)$, capital-goods production was higher than consumer-goods 
production for 44 out of 60 months, i.e., for nearly 70 percent of the phase. That fact supports the idea that the structure of production was distorting in Phase 1, however, only in Phase 2 did this distortion reach the point of irreversibility. This is consistent with $\mathrm{ABCT}$, where production of capital goods grows faster than that of consumer goods in the boom phase with this production only to be eventually corrected by market forces during a subsequent bust.

The interest rate is also displayed in the graph, showing a trajectory of successive declines and then a sustained low rate through the T-boom and M-boom (see scale values on the left vertical axis of Figure 7 below).

Figure 7. Interest-Rate Impact on the Structure of Production

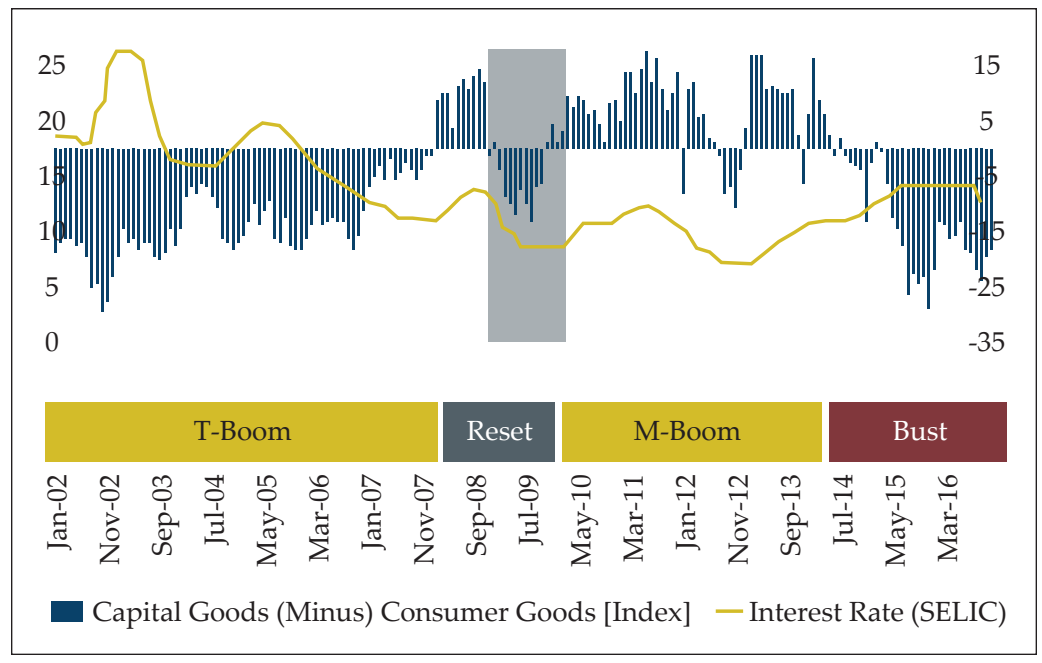

Source: Central Bank of Brazil (BCB). SELIC series 4390.

\section{PHASE 3: RECESSION}

In the second quarter of 2014, Brazil's output began to fall. The next graph shows year-on-year growth in Brazilian GDP on a quarterly basis. GDP shrank for 11 consecutive quarters, resulting in the longest recession in a century. 
Figure 8. Quarterly GDP Growth During the M-Boom and Bust Periods 2009-16

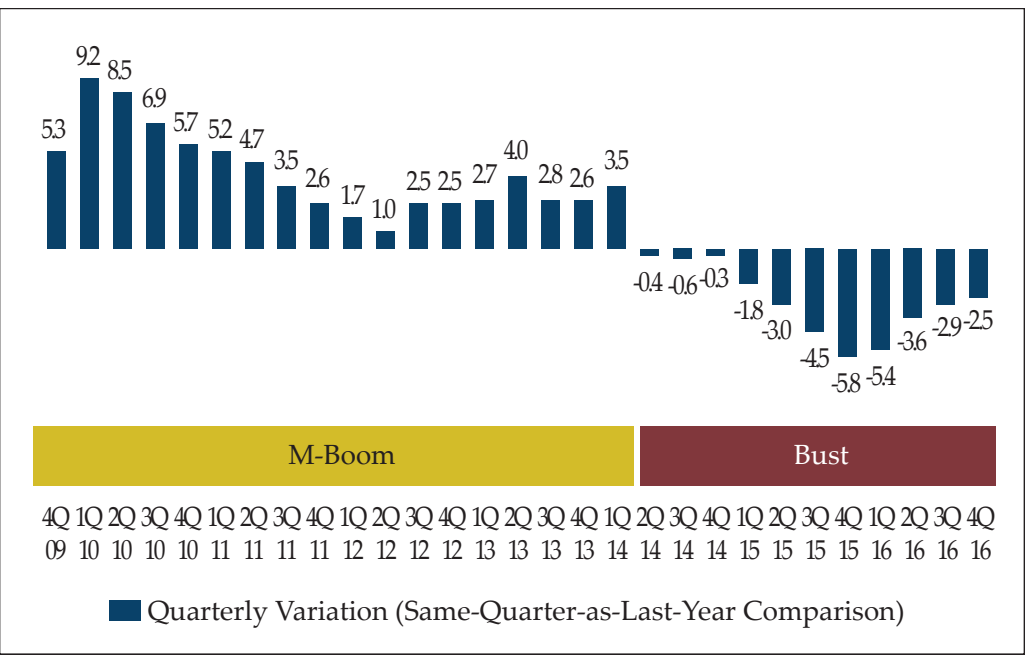

Source: Brazilian Institute of Geography and Statistics (IBGE). Quarterly GDP growth series 5932 .

Credit had a delayed impact on Phase 3 (bust) of the business cycle. Figure 9 shows the long expansion of credit as a percentage of GDP for both businesses and individuals. For 2012, credit grew at a 5.7 percent rate for businesses and a 6 percent rate for individuals. By 2015, the rates had fallen to 2.4 percent for businesses and 3.1 percent for individuals; both forms greatly slowing with business credit falling faster. The following year, 2016, credit expansion entered a clear tailspin, growing at a rate of -13.4 percent for businesses and -1.2 percent for individuals. 


\section{Figure 9. Credit Expansion and Contraction as a Proportion of GDP (\%)}

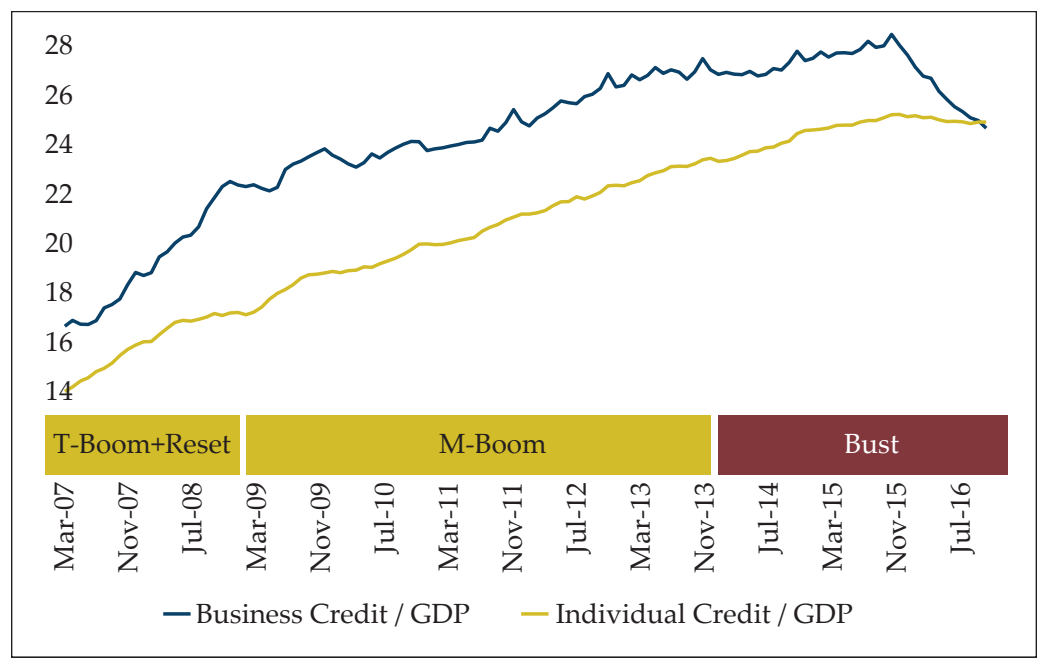

Source: Central Bank of Brazil (BCB). Business credit/GDP series 20623. Individual credit/GDP series 20624.

As can be seen in Figure 9 above, there was no observable contraction in credit at the beginning of the bust. Instead, credit levels fell only in the third year (2016), with businesses cutting back ( -13.4 percent) much more than individuals ( -1.2 percent) as confirmed in Table 7 below. 
Table 7. Business and Individual Credit as a Percentage of GDP (M-Boom to Bust)

\begin{tabular}{|l|l|l|l|}
\hline \multirow{2}{*}{ Phase } & Year & $\begin{array}{l}\text { Business credit/GDP } \\
\text { (Annual change) }\end{array}$ & $\begin{array}{l}\text { Individual credit/GDP } \\
\text { (Annual change) }\end{array}$ \\
\hline 2 & 2010 & $1.2 \%$ & $6.2 \%$ \\
\cline { 2 - 4 } (M-Boom sans Reset) & 2011 & $5.4 \%$ & $5.5 \%$ \\
\cline { 2 - 4 } & 2012 & $5.7 \%$ & $6.0 \%$ \\
\cline { 2 - 4 } & 2013 & $2.3 \%$ & $4.7 \%$ \\
\hline \multirow{3}{*}{ (Bust) } & 2014 & $1.1 \%$ & $4.5 \%$ \\
\cline { 2 - 4 } & 2015 & $2.4 \%$ & $3.1 \%$ \\
\cline { 2 - 4 } & 2016 & $-13.4 \%$ & $-1.2 \%$ \\
\hline
\end{tabular}

Source: Central Bank of Brazil. Business credit/GDP series: 20623. Individual credit/ GDP series: 20624.

Recession is thehealthy part of the recovery process because it is the adjustment of the economy back to its original condition (Rothbard, 2009). Without further state interference, the economy will move back to equilibrium, prices and wages will fall, and unviable businesses will go bankrupt. The recession is the economy's attempt to adjust to the state of current natural time preferences, utility, and scarcity, which is not necessarily the pre-boom state of affairs because of at least slight changes that could have occurred in these underlying phenomena. This can be observed in the production of capital and consumer goods in Figure 10 below (base year $2012=$ 100). Production of capital goods falls steadily between 2014 and 2016, a decline greater than that experienced by consumer goods. 
Figure 10. Structure of Production of Capital and Consumer Goods Indices for Phases 2 and 3 (Base Year $2012=100$ )

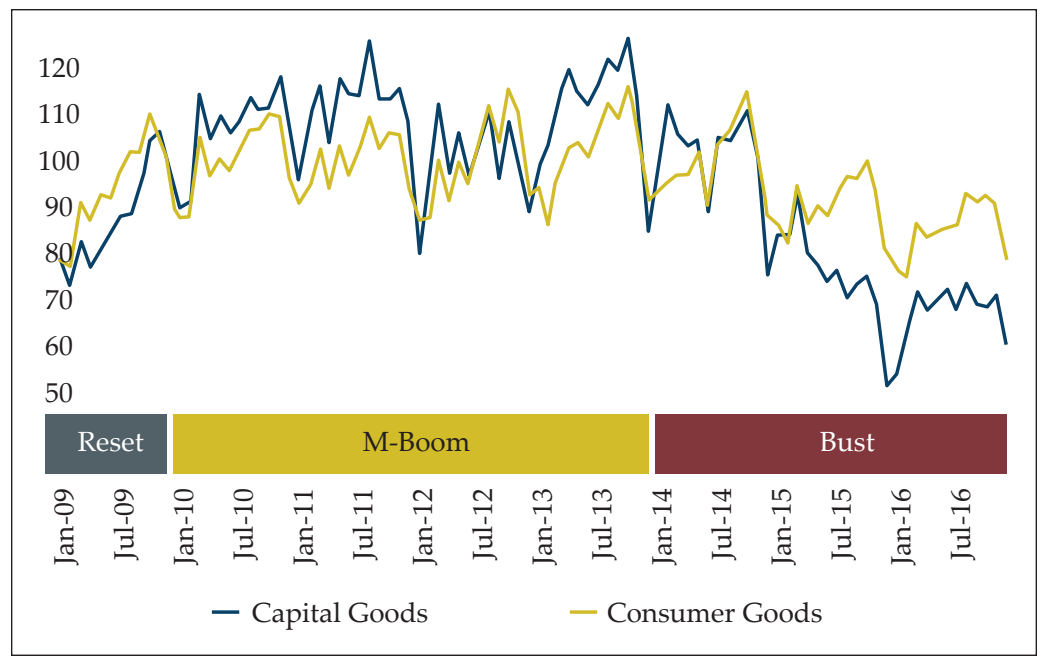

Source: Central Bank of Brazil (BCB). Capital goods series 21863. Consumer goods series 21865 .

Despite the visible difference in the two series in the graph, the phenomenon of returning to "the old standards before the crisis" affected industrial production. The authors noted the six months with the highest average value in the boom and the lowest average value in the bust. They also compared the lowest average value during the recession with the six months before the Reset in which similar values could be found. Results will show how many years of performance the economy lost in the bust phase. The reason for searching before the Reset is the Brazilian government's reaction to the peak of the U.S. financial crisis in September 2008 (which led to muddled data for 2009). The authors used six-month averages to insulate the results from monthly seasonal variations.

For the production of consumer goods, the highest performing six months in the M-boom was the second half of 2013, when the index averaged 106.56. The worst six-month period in the bust was the first half of 2016, with an average of 82.16. The economy then returned to the type of output levels it had in the first six months of 2005 when the index averaged 82.63. That is, consumer-goods production returned to the level of 11 years previous. 
For capital goods, the highest level was in the second half of 2011, with the index averaging 115.31. The lowest average in the recession was 66.53, recorded in the first six months of 2016. Capital-goods production fell back to levels not witnessed since the first half of 2004. In other words, this was a decline lasting 12 years.

Table 8 below summarizes the performances of capital and consumer goods in terms of all averages combined among the M-boom and Bust stages.

Table 8. Recession Adjustment Process (Industrial Production)

\begin{tabular}{|l|l|l|l|l|}
\hline $\begin{array}{l}\text { Type of } \\
\text { Goods }\end{array}$ & $\begin{array}{l}\text { Highest } \\
\text { Output } \\
\text { (M-Boom) }\end{array}$ & $\begin{array}{l}\text { Lowest } \\
\text { Output } \\
\text { (Bust) }\end{array}$ & $\begin{array}{l}\text { Year Before Reset } \\
\text { When Output Was as } \\
\text { Low as the Bust }\end{array}$ & $\begin{array}{l}\text { Fall in Output } \\
\text { (Approximate Years) }\end{array}$ \\
\hline Consumer & $\begin{array}{l}\text { 2nd half* } \\
\text { of 2013 }\end{array}$ & $\begin{array}{l}\text { 1st half } \\
\text { of 2016 }\end{array}$ & $\begin{array}{l}\text { 1st half } \\
\text { of 2005 }\end{array}$ & $\begin{array}{l}11 \\
\text { years }\end{array}$ \\
\hline Capital & $\begin{array}{l}\text { 2nd half } \\
\text { of 2011 }\end{array}$ & $\begin{array}{l}\text { 1st half } \\
\text { of 2016 }\end{array}$ & $\begin{array}{l}\text { 1st half } \\
\text { of 2004 }\end{array}$ & $\begin{array}{l}\text { 12 } \\
\text { years }\end{array}$ \\
\hline
\end{tabular}

*half $=$ two consecutive quarters

Table 8 shows that capital goods returned to their initial condition in the T-boom phase. This is consistent with $\mathrm{ABCT}^{\prime} \mathrm{s}$ prediction that the economy would return to approximate pre-boom levels (Mises 2008). Consumer goods declined to their level of 11 years previous (in the first half of 2005). Capital goods fell even more, falling to their level of 12 years previous (in the first half of 2004). The Brazilian economy returned to its approximate initial conditions when the boom first started in 2004.

\section{INFLATION THROUGHOUT THE BUSINESS CYCLE}

Brazil's economic history is full of inflation inanity. Between 1964 and 1994, the nation's accumulated inflation was more than one quadrillion percent when measured by the IGP-DI index (Leitão 2011, 23). The inflation tsunami was finally brought under control by the 1994 Real Plan, which implemented a new currency and several other important measures. Inflation in the year following 
the plan was approximately 13 percent. Although this is not a remarkable achievement per se, it is impressive when compared to 1993 when inflation averaged 30 percent per month.

The Central Bank of Brazil (BCB) has an inflation target that guides its interest-rate policy. If inflation is rising or expected to rise, interest rates will rise and the opposite occurs for falling inflation. In addition, BCB sets upper and lower limits of two percent (above and below its inflation goal), which means that inflation must be inside this pre-established range. $\mathrm{BCB}$ uses the Broad National Consumer Price Index (Índice Nacional de Preços ao Consumidor Amplo, IPCA for short) as its official measure to guide its interest-rate decisions (Central Bank of Brazil 2016b).

\section{Figure 11. Consumer Inflation}

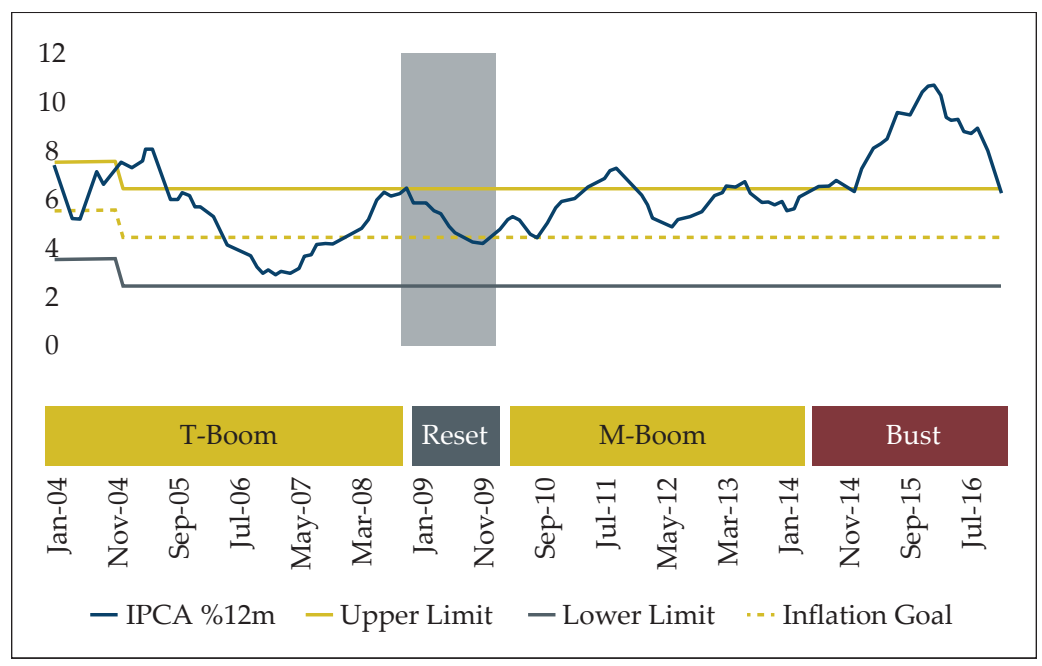

Source: Central Bank of Brazil (BCB). IPCA series 13522. Inflation target series 13521.

Figure 11 above shows the performance of consumer inflation during the three phases. The graph is very clear when it comes to $\mathrm{BCB}$ inflation-policy effectiveness. The periods in which inflation was mostly outside of $\mathrm{BCB}^{\prime} \mathrm{s}$ target range were mainly in the bust phase. However, as further analysis will show, inflation was postponed rather than tamed by $\mathrm{BCB}$ interventions. 
According to Table 9 below, in 49 months of Phase 1, inflation was within $\mathrm{BCB}^{\prime}$ s target range, a success rate of approximately 88 percent. Inflation averaged about 5.3 percent per annum during this period. Phase 2 had similar results, however, it was the period when government interest-rate interventions became aggressive. Although 82 percent of the months in Phase 2 displayed inflation within $\mathrm{BCB}^{\prime}$ s target range, inflation was artificially suppressed by many state actions. ABCT predicts that consumer inflation will rise in a boom and fall in a bust. However, if government interventions prevent inflation from rising in a boom, it would be rational to expect that a subsequent bust will be hyper-affected by the inflationary forces that were artificially suppressed during the boom.

Sure enough, in the bust, Brazil's inflation rate was higher than in any other phase. In January 2016, inflation reached a peak of 10.71 percent, the highest level in the previous 13 years. During the bust, inflation was within $\mathrm{BCB}^{\prime}$ 's target range for only five months out of 34 , giving the central bank a rather unimpressive success rate of 15 percent.

Table 9. Inflation-Goal Performance

\begin{tabular}{|l|l|l|l|l|l|l|}
\hline Phase & Label & $\begin{array}{l}\text { Months } \\
\text { within } \\
\text { target } \\
\text { range }\end{array}$ & $\begin{array}{l}\text { Months } \\
\text { outside } \\
\text { target } \\
\text { range }\end{array}$ & $\begin{array}{l}\text { \% } \\
\text { within } \\
\text { target } \\
\text { range }\end{array}$ & $\begin{array}{l}\text { Total } \\
\text { months } \\
\text { in } \\
\text { period }\end{array}$ & $\begin{array}{l}\text { Average } \\
\text { inflation } \\
\text { rate } \\
\mathbf{( \%} \text { in period) }\end{array}$ \\
\hline 1 & T-boom & 49 & 7 & $88 \%$ & 56 & $5.3 \%$ \\
\hline 2 & $\begin{array}{l}\text { Reset }+ \\
\text { M-boom }\end{array}$ & 54 & 12 & $82 \%$ & 66 & $5.7 \%$ \\
\hline 3 & Bust & 5 & 29 & $15 \%$ & 34 & $8.2 \%$ \\
\hline Total & & $\mathbf{1 0 8}$ & $\mathbf{4 8}$ & $\mathbf{6 9 \%}$ & $\mathbf{1 5 6}$ & $\mathbf{6 . 1 \%}$ \\
\hline
\end{tabular}

For the classification of inside or outside the target range, the inflation range set by BCB was used (Central Bank of Brazil 2018).

\section{How Government Interventions Postponed Economic Recovery}

As mentioned above, government interventions in Phase 2 postponed inflation that would have been ordinarily felt during a period of credit expansion. Therefore, higher rates of inflation were experienced only in Phase 3, and still only in a subdued manner. 
Inflation as measured by IPCA has two main components: a) "free market" prices; b) government-controlled prices ("Petrobras Approves New Fuel Price Readjustment Policy" 2013). The first component covers all prices that are set by voluntary exchanges in the "free market," while the latter category covers prices set by government decree via its agencies, companies, and structures. Government-controlled prices are also set at the federal, state, and municipal levels. In May 2016, government-controlled prices represented nearly a quarter of the IPCA (Central Bank of Brazil 2016a) and that proportion is similar to the one that prevailed in earlier years (Solomao 2013). In Brazil, the government uses its discretionary authority to influence prices as measured by IPCA. If the government postpones price increases, the index will be held down artificially.

In Phase 2, government interventions intensified. Table 10 below summarizes many of those decisions which worked to postpone inflation (which should have been felt during the M-boom but was not felt until the bust). 


\section{Table 10. Brazilian Government Interventions to Suppress the Inflation Index (Selected Indices)}

\begin{tabular}{|c|c|c|c|}
\hline $\begin{array}{l}\text { IPCA } \\
\text { Components }\end{array}$ & Period & Intervention & $\begin{array}{l}\text { Weight in } \\
\text { Controlled Prices } \\
\text { (May 2016) }\end{array}$ \\
\hline $\begin{array}{l}\text { Residential } \\
\text { electric power }\end{array}$ & $\begin{array}{l}\text { Phase } 2 \\
\text { (M-boom) }\end{array}$ & $\begin{array}{l}\text { Government obliged companies } \\
\text { to automatically renew } \\
\text { concessionary contracts, resulting } \\
\text { in an unstable environment for } \\
\text { private investment (power } \\
\text { distributors are mainly private). } \\
\text { In addition, government } \\
\text { implemented a policy to subsidize } \\
\text { part of the costs of residential } \\
\text { power in return for the private } \\
\text { sector not raising prices } \\
\text { (Landim 2014). }\end{array}$ & $15.01 \%$ \\
\hline $\begin{array}{l}\text { Residential } \\
\text { gas }\end{array}$ & $\begin{array}{l}\text { Phase } 2 \\
\text { (M-boom) }\end{array}$ & $\begin{array}{l}\text { State-controlled oil company } \\
\text { Petrobras lost nearly R } \$ 10.5 \\
\text { billion by not adjusting gas } \\
\text { prices (Soares 2014). }\end{array}$ & $4.85 \%$ \\
\hline \multirow[t]{2}{*}{ Gasoline } & $\begin{array}{l}\text { Phase } 2 \\
\text { (M-boom) }\end{array}$ & $\begin{array}{l}\text { Petrobras accepted subsidies on } \\
\text { gasoline through cuts in the } \\
\text { gasoline tax (CIDE) in order to not } \\
\text { increase inflation. At that time, the } \\
\text { government estimated that prices } \\
\text { should rise } 22 \% \text { but resorted to } \\
\text { subsidies instead of allowing prices } \\
\text { to rise. This decision was against } \\
\text { Petrobras management's } \\
\text { recommendation ("Petrobras } \\
\text { Approves New Fuel Price } \\
\text { Readjustment Policy" 2013). }\end{array}$ & $16.90 \%$ \\
\hline & & Total & $36.76 \%$ \\
\hline
\end{tabular}

All the interventions in Phase 2 deferred inflation to the future. The effects were felt only after the M-boom, when most of the artificially low prices could not be sustained. In 2013, there was a 15.65-percent fall in residential electric-power prices as a result of government intervention. However, in 2014 and 2015, prices rose 17.06 percent and 50.99 percent, respectively. ${ }^{14}$

\footnotetext{
${ }^{14}$ Accumulated inflation for each year. Data from BCB series 4453.
} 
The following graph, Figure 12, juxtaposes year-by-year IPCA controlled prices with IPCA free-market prices. The graph shows government-controlled prices sliding way below free-market prices in both boom phases (but especially in the M-boom years of 2011-13) before disproportionately racing ahead of them in the bust years of 2014-15, reaching a peak of 18.07 percent in 2015. At a minimum, the striking divergence between the two series between 2011 and 2015 evokes questions about its cause.

\section{Figure 12. Controlled Prices Compared to Free-Market Prices (Annual Averages)}

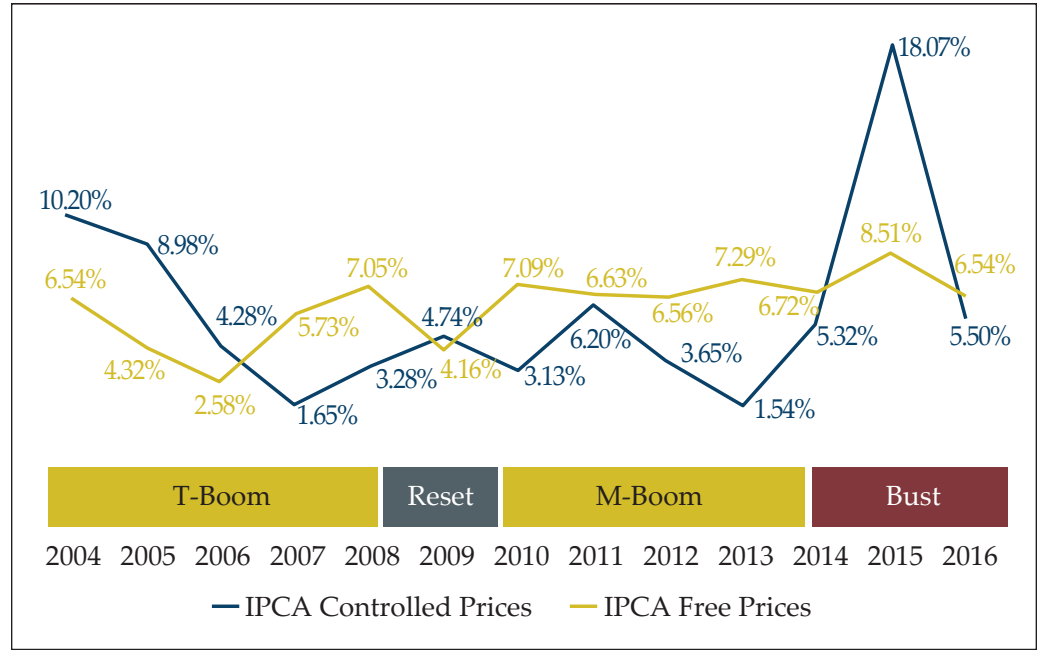

Source: Central Bank of Brazil (BCB). IPCA series 4449. IPCA free-market series 11428.

Controlled prices fell from an annual rate of 5.68 percent in Phase 1 to 3.85 percent in Phase 2, a fall of 32 percent. During the same period, free market prices rose from 5.24 percent to 6.34 percent, a rise of 21 percent. Controlled prices then rose by an annual average of 9.63 percent in Phase 3, a 150.1-percent increase when compared to Phase 2. Free market prices also rose in Phase 3, but the average increase was about 14.4 percent when compared to Phase 2 (see Table 11 below). 
Table 11. Annual Inflation: Controlled vs. Free-Market Prices

\begin{tabular}{|l|l|l|l|}
\hline Phase & Label & Government-Controlled Prices & Free-Market Prices \\
\hline 1 & T-Boom & $5.68 \%$ & $4.58 \%$ \\
\hline 2 & Reset + M-Boom & $3.85 \%$ & $5.57 \%$ \\
\hline 3 & Bust & $9.63 \%$ & $6.34 \%$ \\
\hline & Average & $5.89 \%$ & $5.37 \%$ \\
\hline
\end{tabular}

Without question, Brazil's government made its recession worse through its manipulation of prices. Instead of leaving prices to fluctuate normally in response to market forces, the government used its power to influence prices as part of its interventionist agenda. Price adjustment, though, cannot be postponed forever. The result was that when the recession finally arrived in 2014, inflation was not able to fall as part of the natural adjustment process. Because of past government interference, prices first had to perversely spike in 2014-15 (the Bust) to compensate for past suppression.

The bust is the start of the recovery process (Rothbard 2009) when prices fall, malinvestments are liquidated, bankruptcies rise, and the high debt ratio for households and companies remains steady or falls (Salerno 2012). However, one main component of the recovery process-prices-was not aligned with the business cycle. Prices had to rise because of government suppression during the boom phases, and this had to occur in the recession. The bust's increase in inflation combined with negative industrial production was a deadly combination in hindering business profitability.

If the government had not held down prices in the boom it would be realistic to expect that inflation would have fallen in the early months of the bust (2014), and as a consequence, the recovery process would have been faster. Instead, inflation only began falling about two years after the recession began.

\section{EXPECTED RESULTS AND OBSERVED FACTS}

The observed facts from the recent Brazilian experience, when compared with $\mathrm{ABCT}$ expectations, are not surprising. Table 12 
below reveals that 13 out of 15 (87 percent) expected results from $\mathrm{ABCT}$ theory were confirmed by the data.

The variables that fell outside expectations were three: savings, inflation, and money supply. Savings actually rose 7.4 percent in the first year of the bust (2014). However, in 2015 it fell 11.3 percent, turning the net effect negative. Individuals did not increase savings in the period. However, for consumption the fall was far greater. As a standalone variable, savings declined but when compared to consumption, it experienced a lower decline.

As for inflation, as discussed in the previous section, Brazil did not experience a sharp fall during the bust. Government intervention prevented controlled prices from rising during the boom, which meant that they had to adjust upwards in the bust. Thus, controlled prices climbed 18 percent in 2015. If the government had not manipulated prices, then prices almost certainly would have fallen in the bust period.

As for the money supply (M2), as Table 4 above indicates, while the average growth rate in M2 was certainly not negative, it was about 35 percent of what it was during the T-boom. M1 was about 29 percent of what it was during the T-boom. The growth rate of both measures of the money supply had declined significantly. 
Table 12. ABCT Realized Results

\begin{tabular}{|l|l|l|l|l|}
\hline Variable & $\begin{array}{l}\text { T-Boom and } \\
\text { M-Boom }\end{array}$ & Observed? & Bust & Observed? \\
\hline GDP & Rise & Yes & Fall & Yes \\
\hline Interest rate & Fall & Yes & Rise & Yes \\
\hline $\begin{array}{l}\text { Money supply } \\
\text { (M2) }\end{array}$ & Rise & Yes & $\begin{array}{l}\text { Fall/ } \\
\text { Stagnate }\end{array}$ & No* \\
\hline Credit & Rise & Yes & Fall & Yes \\
\hline Savings & $\begin{array}{l}\text { Stagnate, fall, or } \\
\text { rise less than } \\
\text { credit expansion }\end{array}$ & Yes & Rise & No \\
\hline $\begin{array}{l}\text { Industrial } \\
\text { production } \\
\text { (higher orders) }\end{array}$ & $\begin{array}{l}\text { Rise more than } \\
\text { lower orders }\end{array}$ & Yes & $\begin{array}{l}\text { Fall more than } \\
\text { lower orders }\end{array}$ & Yes \\
\hline $\begin{array}{l}\text { Industrial } \\
\text { production } \\
\text { (lower orders) }\end{array}$ & $\begin{array}{l}\text { Rise less than } \\
\text { higher orders }\end{array}$ & Yes & $\begin{array}{l}\text { Fall less than } \\
\text { higher orders }\end{array}$ & Yes \\
\hline \begin{tabular}{l} 
Inflation \\
\hline
\end{tabular} & Rise & Yes & Stable or lower & No \\
\hline
\end{tabular}

*See CAG for M2 in Table 4 above. While the growth rate of M2 was not negative it was on average a little more than a third of what it was during the T-Boom.

\section{CONCLUSIONS}

This study intended to analyze the 2004-16 Brazilian business cycle through the lens of Austrian Business Cycle Theory (ABCT). From $\mathrm{ABCT}, 16$ expected results were delineated and nearly all of them were empirically confirmed, thus strong supporting evidence in the recent Brazilian experience was found for $\mathrm{ABCT}$. The boom initiated in 2004, the structure of production began to be distorted, and this distortion became more pronounced during the second part of this boom. The Brazilian government continually lowered the interest rate, bringing it low enough to create an artificial boom followed by a severe bust that was not just another typical "flight of the chicken," but Brazil's most severe recession in more than a century.

This study's findings reinforce ABCT's accuracy in explaining business cycles. In this day and age, it is surprising that mainstream economists still ignore or misinterpret ABCT (Garrison 1999, Evans 
2010, Salerno 2012). As for politicians and regulators, there is no way that governments can precisely manage a modern economy through monetary and interest-rate central planning, and it is certainly not possible to do so without temporarily warping an economy's production structure.

This article aspires to be one of the first scientific studies of the recent macroeconomic crisis in Brazil to utilize the theoretical framework of ABCT. The hope is that it will introduce a fresh perspective in economics for Brazilian economists, business executives, entrepreneurs, academics, and political leaders who can effect social change in Brazil. In a recent survey (Heritage Foundation 2018), Brazil ranked 153 out of 180 nations in terms of having one of the lowest levels of economic freedom in the world. The authors hope that this study will help reverse Brazil's dismal ranking in economic liberty and bring about lasting changes in Brazil for the economic betterment of its 210 million people.

\section{REFERENCES}

Amorim, Ricardo. 2016. After the Storm. São Paulo: Prata Editora.

Block, Walter E., William Barnett II, and Joseph T. Salerno. 2006. “The Relationship Between Wealth or Income and Time Preference is Empirical, Not Apodictic: A Critique of Rothbard and Hoppe." Review of Austrian Economics 19, no. 1: 69-80.

Brazilian Institute of Geography and Statistics. 2004. Industrial Indicators: Production. Methodological Series Reports 31. Rio de Janeiro: 2004 http://www.ibge.gov.br/home/estatistica/indicadores/industria/ pimpfbr/srmindconjind.pdf.

Carilli, Anthony M. and Gregory M. Dempster. 2001. “Expectations in Austrian Business Cycle Theory: An Application of the Prisoner's Dilemma." Review of Austrian Economics 28, no. 2: 151-65.

Central Bank of Brazil. 2016a. Department of Investor Relations and Studies. Frequently Asked Questions. Administered Prices. Brasilia: 2016. http://www.bcb.gov.br/conteudo/home-ptbr/FAQs/ FAQ\%2005-Pre\%C3\%A7os\%20Administrados.pdf

- 2016b. Department of Investor Relations and Studies. Frequently Asked Questions. Price Indexes in Brazil. Brasilia: 2016. http://www.bcb. 
gov.br/conteudo/home-ptbr/FAQs/FAQ\%2002-\%C3\%8Dndices\%20 de\%20Pre\%C3\%A7os\%20no\%20Brasil.pdf

_ 2018. Inflation Targeting. Brasilia: 2018. http://www.bcb.gov.br/Pec/ relinf/Normativos.asp

Cochran, John P. 2001. "Capital-Based Macroeconomics: Recent Developments and Extensions of Austrian Business Cycle Theory." Quarterly Journal of Austrian Economics 4, no. 3: 17-25.

Coelho, Christiano, Joao Manoel Pinho De Mello, and Bruno Funchal. 2012. "The Brazilian Payroll Lending Experiment." Review of Economics and Statistics 94, no. 4: 925-34.

Cury, Anay and Daniel Silveira. 2017. “GDP Slips 3.6\% in 2016, Brazil Has Worst Recession in History." Globo, 3 Mar. https:/g1.globo.com/ economia/noticia/pib-brasileiro-recua-36-em-2016-e-tem-pior-recessao-da-historia.ghtml.

Engelhardt, Lucas M. 2009. "Comment on 'A Capital-Based Theory of Secular Growth."' Quarterly Journal of Austrian Economics 12, no. 2: 60-62.

—_. 2012. "Expansionary Monetary Policy and Decreasing Entrepreneurial Quality." Quarterly Journal of Austrian Economics 15, no. 2: 172-94.

Evans, Anthony J. 2010. "What Austrian Business Cycle Theory Does and Does Not Claim as True." Economic Affairs 30, no. 3: 70-71.

Evans, Anthony J. and Toby Baxendale. 2008. “Austrian Business Cycle Theory in Light of Rational Expectations: The Role of Heterogeneity, the Monetary Footprint, and Adverse Selection in Monetary Expansion." Quarterly Journal of Austrian Economics 11, no. 2: 86-87.

Veloso, Fernando, Pedro C. Ferreira, Fábio Giambiagi, and Samuel De Abreu Pessôa. 2013. Economic Development: A Brazilian Perspective. Rio de Janeiro: Elsevier.

Garrison, Roger. 1978. "Austrian Macroeconomics: A Diagrammatical Exposition." Pp. 167-204 in New Directions in Austrian Economics, ed. Louis M. Spadaro. Kansas City: Sheed, Andrews, and McMeel. 1997. "The Austrian Theory of the Business Cycle." Pp. 23-27 in Business Cycles and Depressions, ed. David Glasner. New York: Garland. 
—_ 1999. "Hayek Made No Contributions?" The Freeman 49, no. 5: 6-7.

- 2001. Time and Money: The Macroeconomics of Capital Structure. Abingdon, U.K.: Routledge.

— . 2004. "Overconsumption and Forced Saving in the Mises-Hayek Theory of the Business Cycle." History of Political Economy 36, no. 2: 323-49.

- 2006. "Natural and Neutral Rates of Interest in Theory and Policy Formulation." Quarterly Journal of Austrian Economics 9, no. 4: 57-68.

— . 2012. "Natural Rates of Interest and Sustainable Growth." Cato Journal 32, no. 2: 423-37.

Giambiagi, Fabio, Lavinia Barros de Castro, Andre Arruda Villela, and Jennifer Hermann. 2016. Contemporary Brazilian Economics, 3d ed. Rio de Janeiro: Elsevier.

Giménez Roche, Gabriel A. 2014. "Entrepreneurial Ignition of the Business Cycle: The Corporate Finance of Malinvestment." Review of Austrian Economics 29, no. 3: 253-76.

Haberler, Gottfried. 1983. "Money and the Business Cycle." The Austrian Theory of the Trade Cycle and Other Essays. Auburn, Ala.: Ludwig von Mises Institute.

Hayek, Friedrich A. 1931. "The 'Paradox' of Saving." Economica 32: 125-69.

— 1933. Monetary Theory and the Trade Cycle. London: Jonathan Cape.

_ . 1936. "The Mythology of Capital." Quarterly Journal of Economics 50, no. 2: 199-228.

- 1945. "The Use of Knowledge in Society." American Economic Review 35, no. 4: 519-30.

- 2008. Prices and Production and Other Works: F.A. Hayek on Money, the Business Cycle, and the Gold Standard, ed. Joseph T. Salerno. Auburn, Ala.: Ludwig von Mises Institute.

Hennings, Katherine and Mario Mesquita. 2008. "Capital Flows to the Brazilian Economy: 2003-07." BIS Papers 44: 103-19. https://www.bis. org/publ/bppdf/bispap44f.pdf 
Heritage Foundation. 2018. 2018 Index of Economic Freedom. Washington, D.C.: Heritage Foundation. https://www.heritage.org/index/

Holcombe, Randall G. 2017. "Malinvestment." Review of Austrian Economics 30, no. 2: 153-67.

Hoppe, Hans-Hermann. 2007. Economic Science and the Austrian Method. 2d ed. Auburn, Ala.: Ludwig von Mises Institute.

Hülsmann, Jorg Guido. 1998. "Toward a General Theory of Error Cycles." Quarterly Journal of Austrian Economics 1, no. 4: 1-23.

Landim, Raquel. 2014. "Energy Subsidy Already Reaches R\$ 63 Billion." Folha De S. Paulo, 16 March. http://www1.folha.uol.com.br/mercado/2014/03/1426076-subsidio-a-energia-ja-atinge-os-r-63-bi.shtml.

Leitão, Miriam. 2011. Brazilian Saga: the Long Struggle of a People for Their Currency. Rio de Janeiro: Record.

Luther, William J. and Mark Cohen. 2014. "An Empirical Analysis of the Austrian Business Cycle Theory." Atlantic Economic Journal 42: 153-69.

Macovei, Mihai. 2015. "The Austrian Business Cycle Theory: A Defense of Its General Validity." Quarterly Journal of Austrian Economics 15, no. 4: 409-35.

Manish, G. P. and Benjamin Powell. 2014. "Capital Theory and the Process of Inter-Temporal Coordination: the Austrian Contribution to the Theory of Economic Growth." Atlantic Economic Journal 42, no. 2: 133-42.

Mankiw, N. Gregory. 2018. Principles of Macroeconomics. 8th ed. Boston: Cengage.

Mises, Ludwig von. 2006. Economic Policy: Thoughts for Today and Tomorrow. 3d ed. Auburn, Ala.: Ludwig von Mises Institute.

- 2008. Human Action: A Treatise on Economics. Scholar's ed. Auburn, Ala.: Ludwig von Mises Institute.

— 2009. The Theory of Money and Credit. Auburn, Ala.: Ludwig von Mises Institute.

-_- 2011. A Critique of Interventionism. Auburn, Ala.: Ludwig von Mises Institute. 
Mueller, Paul D. 2014. "An Austrian View of Expectations and Business Cycles." Review of Austrian Economics 27, no. 2: 199-214.

"On TV, Dilma Raises Tone to Private Banks and Asks Interest Cut." 2012. Veja, 30 April. https://veja.abril.com.br/economia/ na-tv-dilma-eleva-tom-a-bancos-privados-e-pede-corte-em-juros/.

“Petrobras Approves New Fuel Price Readjustment Policy." 2013. Globo, 19 November. http://g1.globo.com/economia/noticia/2013/11/petrobrasaprova-nova-politica-de-precos-de-diesel-e-gasolina.html.

Roque, Leandro. 2015. "The Tragic Legacy of the 'New Economic Matrix': A Chronological Summary." Mises Brasil, 28 August. https://www. mises.org.br/Article.aspx?id=2120.

Rosas, Rafael, and Juliana Machado. 2017. "Vale's Iron Ore Production Hits Record in 2016." Valor, 16 February. http:// www.valor.com.br/empresas/4871504/producao-de-minerio-deferro-da-vale-bate-recorde-em-2016.

Rothbard, Murray N. 2000. America's Great Depression. 5th ed. Auburn, Ala.: Ludwig von Mises Institute.

—. 2009. Economic Depressions: Their Cause and Cure. Auburn: Ludwig von Mises Institute. PDF e-book. https://mises.org/library/ economic-depressions-their-cause-and-cure- 4 .

Salerno, Joseph T. 2001. "Does the Concept of Secular Growth Have a Place in Capital-Based Macroeconomics?" Quarterly Journal of Austrian Economics 4, no. 3: 43-61.

— . 2012. "A Reformulation of Austrian Business Cycle Theory in Light of the Financial Crisis." Quarterly Journal of Austrian Economics 15, no. 1: 3-44.

Soares, Pedro, and Samantha Lima. 2014. "Petrobras 'Loses' R\$10 Billion with Gas Subsidy." Folha De S. Paulo, 25 May. http://www1.folha.uol. com.br/mercado/2014/05/1459598-petrobras-perde-r-10-bilhoes-comsubsidio-a-gas.shtml.

Solomao, Alexa. 2013. "Without Controlled Prices, IPCA Would Be at 8.0\%." Estadao, 18 August. http://economia.estadao.com.br/noticias/ geral,sem-precos-controlados-ipca-estaria-em-8-0-imp-,1065290.

Young, Andrew T. 2009a. "A Capital-Based Theory of Secular Growth." Quarterly Journal of Austrian Economics 12, no. 1: 36-51. 
— 2009b. "A Capital-Based Theory of Secular Growth: Reply to Engelhardt." Quarterly Journal of Austrian Economics 12, no. 2: 63-67.

World Bank. 2018. “Brazil.” Data.WorldBank.Org. https://data.worldbank. org/country/brazil?view=chart

—. 2019. “Gross Savings (Current US\$)" Data.WorldBank.Org. https://data.worldbank.org/indicator/ny.gns.ictr.zs https://data.worldbank.org/indicator/NY.GNS.ICTR.CD?locations=BR 